\title{
Suicidas e foliões: chanchada, carnavalização e realismo no filme Tudo azul, de Moacyr Fenelon (1951) ${ }^{1}$
}

\author{
Suicides and revelers: \\ chanchada, carnivalization and realism in the film \\ Tudo azul by Moacyr Fenelon (1951)
}

Marcos Napolitano

O cinema e a configuração cultural e política dos anos 1950

No começo dos anos 1950, alguns cineastas brasileiros discutiam como construir uma cinematografia "nacional e popular" que fosse produzida fora dos circuitos dos grandes estúdios e que valorizasse temas e personagens brasileiros. Além disso, trabalhavam para conseguir que o Estado elaborasse leis que apoias-

Marcos Napolitano é doutor em História Social, livre-docente de História do Brasil e professor do Departamento de História da Universidade de São Paulo (USP), Brasil (napoli@usp.br).

Este artigo foi desenvolvido com o apoio da Bolsa Produtividade em Pesquisa/CNPq.

Artigo recebido em 17 de dezembro de 2012 e aprovado para publicação em $1^{\circ}$ de abril de 2013.

Est. Hist., Rio de Faneiro, vol. 26, no 51, p. 133-153, janeiro-junho de 2013. 
sem o cinema brasileiro e o defendessem da avassaladora hegemonia do cinema norte-americano sobre o circuito de exibição. Nesse clima político-cultural foram realizados congressos de cinema que, ao lado de medidas protecionistas, sintetizavam a busca de uma cinematografia que falasse do "homem brasileiro" (Mello e Souza, 2005).

Aquela era uma época em que a jovem democracia política brasileira, a "República de 1946", ainda exercitava linguagens e instituições que apontavam para outra possível relação entre o Estado, as elites políticas e as classes populares. Em lugar dos velhos políticos empertigados e oligarcas da velha República pré-1930, surgia o líder carismático que se comunicava com as massas ao mesmo tempo em que se equilibrava sobre um sistema de partidos nacionais ainda frágil e sujeito a crises políticas. As classes populares, notadamente o operariado urbano, se tornavam um ator político-eleitoral, fator decisivo nas eleições, apesar das amplas restrições ao voto. Por conta da eleição de Getúlio Vargas em 1950, a promessa de uma democracia de massas e de uma política econômica norteada pelo desenvolvimentismo nacional-estatista voltava a dar o tom da política brasileira. O nacionalismo era compartilhado por vários grupos ideológicos mais à esquerda em graus e formas variadas - trabalhistas, comunistas e socialistas - e exigia um novo olhar sobre as classes populares, vistas como a base social desse projeto político e econômico. No Brasil sob o contexto da Guerra Fria, o nacionalismo era visto como uma estratégia possível para escapar à política de alinhamento automático com os EUA, que, sob o pretexto do combate ao comunismo, reforçavam sua presença econômica e militar em várias regiões do mundo.

A esquerda comunista ligada ao PCB se identificava com o nacional-popular como forma de defesa da nação contra o "imperialismo", mas desde 1950 estava voltada para uma estratégia de provocar o levante das massas camponesas, vistas como a força de combate da "revolução brasileira", conforme o "Manifesto de Agosto" de 1950. Nessa opção política, comunistas se isolaram de outras forças nacionalistas e de esquerda, o que não impediu que seus militantes sindicais e intelectuais reforçassem o campo nacionalista em aliança com outros setores.

No plano cultural, a década de 1950 foi marcada pela forte presença da busca do popular como signo do nacional, processo que era marcado por várias perspectivas ideológicas diferentes, que iam dos setores mais conservadores da direita à esquerda em seus diversos segmentos (socialistas, trabalhistas e comunistas). $\mathrm{O}$ folclorismo, por exemplo, era uma das chaves para representar o popular, e mobilizava intelectuais de diversos matizes, que idealizavam as classes populares como uma comunidade orgânica, isolada no espaço e parada no tempo, portadora de uma alma nacional profunda que se expressava em uma cultura que deveria ser conhecida e preservada (Vilhena, 1997). Os camponeses, o "homem do campo", eram vistos como o protótipo desse povo idealizado. Aos operários, 
os folcloristas reservavam uma dúvida fundamental: como as massas urbanas, submetidas à influencia dissolvente dos meios de comunicação internacionalizados, como o rádio e o cinema, poderiam manter-se como esteio da identidade nacional? Em grande parte, o projeto folclorista visava consolidar uma imagem do povo brasileiro ideal para educar o povo brasileiro real. Se à direita essa idealização visava reforçar os laços da nacionalidade pretensamente orgânica e evitar a agudização dos conflitos sociais, à esquerda o folclorismo deveria ser uma linguagem que valorizasse a nacionalidade ameaçada e reforçasse a identidade popular para a ampliação dos direitos sociais e políticos. A febre folclorista e os debates sobre como representar o povo brasileiro, e consequentemente o próprio país, marcaram o quadro cultural e ideológico da década de 1950 (Velloso, 2002).

O cinema brasileiro não poderia ficar indiferente a esse debate, sobretudo quando feito por realizadores nacionalistas de esquerda comprometidos com a afirmação de um cinema como indústria nacional e expressão cultural. A emergência do popular como ator político e representação cultural marcou os debates internos e se misturou aos discursos de defesa do cinema nacional. Para os cineastas que embarcaram nesse projeto, era preciso que a temática, a estética e a forma de produção fossem coerentes entre si na realização de filmes que deveriam divertir e representar o "homem brasileiro". Nesse processo, um grupo de cineastas radicados no Rio de Janeiro, como Alex Viany e Moacyr Fenelon, esboçou uma cinematografia que não queria apenas divertir de maneira fácil, à base de clichês e da tipificação padronizada dos tipos "populares", como nas chanchadas da época. Mas o grupo também não recusava completamente a linguagem do gênero, pois aqueles filmes desvalorizados por muitos intelectuais eram muito populares e, de uma forma ou de outra, levavam as classes populares ao cinema. $\mathrm{O}$ desafio era se aproveitar dos elementos cômicos e do apelo da música popular encenada das chanchadas, para inserir elementos da realidade social e do cotidiano popular. Com isso, os cineastas pretendiam levas às telas situações dramáticas inspiradas na realidade social e representar as classes populares urbanas para além dos preconceitos.

Esse projeto muitas vezes esbarrava nas negociações entre roteiristas, produtores e diretores, sem falar nos limites técnicos e dramáticos que frequentemente transformavam os filmes efetivamente realizados em algo muito diferente dos objetivos e intenções estéticas e ideológicas que lhes serviam de mote. Apesar disso, entre fins dos anos 1940 e início dos anos 1960, foram lançados filmes de apelo popular, em diálogo ora com a chanchada,ora com o neorrealismo italiano e com o melodrama, que tentaram consolidar esse projeto. Em grande parte, como documentos históricos, eles são portadores dos impasses e esperanças não apenas do cinema brasileiro, mas da própria democracia política e social que se esboçou no Brasil do entreditaduras. 


\section{Tudo azul: o projeto e a fatura}

O filme Tudo azul (1951), dirigido por Moacyr Fenelon, pode ser enquadrado nesse processo de revisão do filme-musical e da chanchada na tentativa de realizar uma obra diferenciada, na qual a fantasia musical e a realidade social se encontrassem em um só filme. Não por acaso, o filme foi definido pelo reconhecido crítico literário Anatol Roselfeld como um "filme de carnaval inteligente". Lançado em fevereiro de 1952 em 20 cinemas do Rio, ficou duas semanas em cartaz "com grande sucesso" (Melo, 2006: 91).

Moacyr Fenelon era um personagem central nas discussões sobre a defesa do cinema brasileiro, que convergiam para a tentativa de organizar uma defesa da cinematografia nacional sob a proteção do Estado. ${ }^{2}$ Nessa linha de atuação, em 1949 Fenelon fundou a Associação Brasileira de Cinema, dirigiu o Sindicato Nacional da Indústria Cinematográfica e em 1952 presidiu o I Congresso Nacional de Cinema Brasileiro, em cujo contexto esboçou os projetos de temporada mínima de exibição de filmes nacionais e reforçou a luta pela criação de um instituto de promoção do cinema brasileiro.

Fenelon tem sido destacado pela historiografia do cinema brasileiro como um dos animadores do projeto de cinema independente, na busca de uma cinematografia "nacional-popular", que conciliasse diversão e realismo crítico acessível às massas. Desde a fundação da Atlântida, Fenelon alimentava o projeto de realizar filmes populares alinhavados com mensagens de fundo socialista. Exemplos desse projeto foram os filmes Vidas solitárias e Sob a luz do meu bairro, obras que "acabaram descambando para a chanchada", conforme depoimento de Pedro Lima, jornalista comunista que atuava na cena carioca. Fenelon não era propriamente um homem de partido, como Nelson Pereira dos Santos e Alex Viany, outros importantes realizadores que participaram desse projeto de um cinema popular de "esquerda", mas pelo seu tom nacionalista poderia ser definido como um compagnon de route da esquerda comunista.

Tudo azul narra a angústia do "pequeno funcionário" Ananias (Luiz Delfino), compositor inédito e pai de quatro filhos que trabalha em uma companhia de seguros, a Sevive, mas sonha em ser compositor famoso. Entretanto, o mundo conspira contra seu projeto de vida. No verdadeiro balcão de negócios que era uma emissora de rádio, ele é rejeitado quando oferece uma canção para Jorge Goulart. ${ }^{3}$ A presença de Ananias no mundo do rádio é o mote para o primeiro número musical apresentado no filme, ainda dentro da diegese, no qual Goulart canta Mundo de zinco. Ironicamente, a canção fala de um favelado que é pobre, mas vive feliz e é consagrado como compositor na Mangueira, sabendo-se querido pela comunidade. O oposto, portanto, de Ananias, um suburbano com sonhos de subir na vida. Nesse caso, a mensagem de "fundo socialista" se expres- 
sava em meio a projetos de ascensão social individual que, em boa parte, eram a negação da felicidade coletiva.

Nessa primeira canção do filme, não há clima onírico ou de fantasia. Há uma perspectiva realista, e o que vemos é uma apresentação dentro de um estúdio de rádio. Nesse momento, o rádio não é sonho, mas dura realidade para os compositores anônimos enjeitados que vão oferecer suas canções para as estrelas. É o caso de Ananias. Aliás, a diegese realista, narrada pelo viés do melodrama e da chanchada, predomina no primeiro terço do filme, quando o espectador é apresentado ao infortunado Ananias e seu pequeno mundo sem perspectivas.

Depois de ter sua canção recusada na rádio, logo que o protagonista chega a sua casa somos apresentados a sua mulher, Sofia (Laura Suarez), uma megera que cobra senso prático do marido. Sofia é um personagem típico das chanchadas mais paradigmáticas, a esposa-megera. O objeto da paixão de Ananias é a secretária Maria Clara (interpretada pela cantora Marlene no auge de sua popularidade), colega de trabalho que o despreza, sobretudo por ele ser pobre. Na realidade de Ananias, não há saída no casamento ou fora dele. Para completar o infortúnio, no mundo do trabalho Ananias é humilhado pelo chefe, que cobra responsabilidade, pontualidade e envolvimento com suas tarefas.

Fracassado e oprimido pelo cotidiano medíocre, o sonhador Ananias toma uma decisão radical: suicidar-se. Após ingerir veneno e se despedir dos filhos, ele vaga pelas ruas até encontrar a "Chácara Paraíso", no qual uma figura enigmática, um velho jardineiro chamado João das Rosas, sutilmente barra sua entrada. "Enquanto houver flores cultivadas pela mão do homem, não podemos descrer da humanidade". Um tanto desolado por ser recusado até no paraíso, Ananias volta para o trabalho, mas seu mundo está mudado para melhor, como uma citação às avessas de Felicidade não se compra (It's a wonderful life, 1946) de Frank Capra. Inesperadamente, ele ganha aumento de salário, o senhorio perdoa suas dívidas, sua esposa o recebe cheia de carinho e compreensão, a secretária Maria Clara está perdidamente apaixonada por ele e a diretoria da empresa nomeia o poeta e compositor como "diretor de Felicidade", para evitar que os clientes segurados morram cedo e tragam prejuízo para a Sevive. Os capitalistas sem criatividade dão 'carta branca' para o pequeno funcionário, dublê de compositor, dirigir a empresa, buscando a 'felicidade' dos clientes, sequência que será analisada mais adiante.

A partir desse ponto, o que deveria ser a longa agonia de um suicida se transforma em uma fantasia musical cinematográfica na qual o sonho de ser famoso e consagrado como compositor de Ananias se realiza em um conjunto de canções de vários gêneros, encenadas por artistas de rádio consagrados. São vários números musicais festivos, apresentados quase em sequência, protagonizados por Marlene, Dalva de Oliveira, Blecaute, Linda Batista, Carmélia Alves e 
Jorge Goulart, cantores muito populares à época. Na verdade, a narrativa não chega a explicitar se Ananias tomou a decisão de se matar ou se teve um pesadelo, no qual sonhava que estava se matando. A edição não se define entre o sonho e a realidade, o que pode sugerir um problema de estrutura narrativa, mas empresta um charme involuntário à fantasia musical.

As canções apresentadas passeiam pelos espaços consagrados da música popular: o teatro de revista (Sassaricando, com Virginia Lane, Maria Candelária com Blecaute, Eva, com Marlene); o drama musical (o bolero Deixa essa mulher chorar, com Linda Batista, e a marchinha Apanhador de papel). A brasilidade da cultura popular, tão perseguida pelos nacionalistas da época, aparece em Baião, interpretada por Carmélia Alves. A alusão ao carnaval como festa de rua, tratada a partir de tons melancólicos, aparece na marcha-rancho Grão de areia, com Dalva de Oliveira e a Escola de Samba Império Serrano. ${ }^{4}$

O tom geral das letras dessas canções é o da crônica, desfile de tipos humanos e paisagens sociais, pautando situações da cidade do Rio de Janeiro captadas por um olhar de relance humorístico e ameno que traduz a opção do diretor pelo diálogo com a chanchada. Essa referência talvez não permita explorar a potencialidade realista das situações sugeridas. Nelas estão comentados os flertes improváveis e o dolce far niente carioca (Sassaricando e Eva), a funcionária pública que não trabalha (Maria Candelária), os tipos boêmios (Deixa essa mulher chorar), o fardo das classes populares (Apanhador de papel e Lata d'água). Entretanto, ao mesmo tempo em que a vontade de realismo, eixo do projeto de um cinema nacional-popular de esquerda, se dissolve na crônica carnavalesca, também a perturba. Visto, em perspectiva histórica, dentro de uma determinada tradição cinematográfica, Tudo azul é um momento cultural importante que interroga os limites da chanchada carnavalesca, pela amplitude temática (das situações diegéticas e das canções) e pela inserção do realismo enquanto imagem documental da pobreza, como se verá adiante.

Na fantasia de Ananias, que ocupa boa parte do filme, a busca da liberdade existencial, do reconhecimento artístico e do sucesso material se traduz em coisas mundanas e até questionáveis para a moral de esquerda: "Bigamia", "Dinheiro", "Fama", “Talento", saídas fáceis do universo da chanchada, mas que acabam servindo de contraponto à realidade opressiva do protagonista. Na tensão entre fantasia e realidade (individual e social), o filme não chega a optar por um caminho claro, mantendo o clima leve das chanchadas, ainda que perturbado por temas espinhosos, como o suicídio, a carestia, a frustração do mundo do trabalho e a miséria social das favelas.

Em determinado momento do filme, cansado da sua própria fantasia de fama e sucesso, Ananias experimenta um momento machadiano de "Homem célebre" (“Qualquer coisa que eu faço é sucesso, é insuportável”). É a senha para 
Ananias voltar à realidade, enfrentando-a com a dignidade de "trabalhadorpai-de-família" e homem comum. Como era regra nos filmes que não abriam mão do sucesso, o final aponta para uma reconciliação e até para certo conformismo diante do cotidiano opressor que é denunciado em vários momentos da obra.

A trajetória de Ananias, por outro lado, vai de encontro aos filmes melodramáticos sobre "vidas de compositores", embora remeta a essa tradição (imagem 1). Normalmente, o compositor talentoso e inédito padece seu calvário, mas termina o filme consagrado. Conforme Michel Chion (1997: 272), "como sabemos, o arquétipo do compositor no cinema se baseia no período romântico, ou melhor, em certa imagem que dele se forjou no século XX: o solitário, bon-vivant, arrivista o desgraçado, rejeitado e logo reconhecido".

Imagem 1: $O$ gênio romântico criando. No fotograma, percebemos o culto consagrado pelo cinema da partitura e do piano como símbolos de criação musical. Mesmo para os sambas.

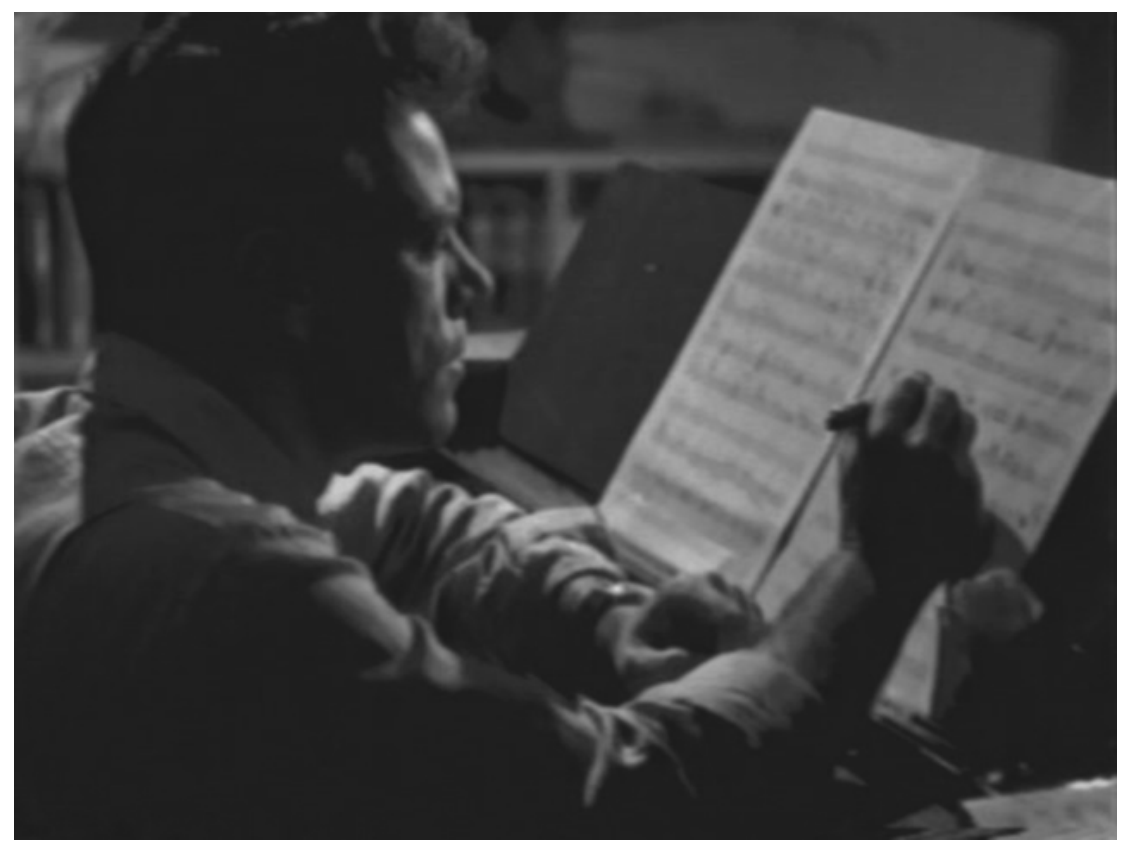

Ananias se encaixa nesse paradigma, ao mesmo tempo em que o inverte. Seu reconhecimento e fama são mostrados como fantasia de suicida. Ao final do filme, saído do pretenso transe moribundo, Ananias se conforma, e até esboça certa felicidade com a volta ao real, com o anúncio do seu quinto filho. 


\section{Tudo azul e o "programa estético" do cinema nacional-popular brasileiro}

Ao tentar conciliar a encenação musical, a leveza das comédias e as inserções do real como espaço de conflito e injustiças, Tudo azul faz parte de uma tradição abortada pelo cinema brasileiro, mas alimentada pelos realizadores e críticos de esquerda (sobretudo comunistas) entre os anos 1940 e 1950. Não por acaso, o projeto original do filme foi pensado pelo roteirista Alinor Azevedo, ex-membro do PCB. Dois elementos centrais do projeto de "cinema popular" que oscilam entre a intenção realista e o espetáculo do filme carnavalesco estão presentes no filme (Melo, 2006: 95): "o compositor popular inédito" e a "ambiências das favelas". Este último elemento não é central em Tudo azul, mas surge de forma contundente e inusitada, como inserção documental rompendo com a diegese fantasiosa por ocasião da apresentação da música Lata d'água.

O projeto original do roteirista Alinor Azevedo chamava-se Mar de rosas. $\mathrm{O}$ indefectível Henrique Pongetti escreveu o argumento e os diálogos. Fenelon aceitou filmar o roteiro, mas com a condição de transformá-lo em uma comédia musical carnavalesca (Melo, 2006: 27). Entretanto, mesmo sem abrir mão dos elementos da chanchada carnavalesca clássica-música, coreografias de teatro de revista e tipos cômicos - o filme traz elementos inovadores, não apenas pelo tratamento dramático, mas também pela inserção de elementos que deveriam fazer a ponte com a realidade social.

Alex Viany classifica Tudo azul como um "filmusicarnavalesco" e não "chanchada" (Melo, 2006: 61), reiterando a tradição que vinha de Favela dos meus amores (Humberto Mauro, 1935) e Moleque Tião (José Carlos Burle, 1943), os míticos filmes desaparecidos que se tornaram referências de um cinema de linguagem popular que propunha conciliar realismo, música e melodrama (Barro, 2007). Alex Viany, em depoimento do final dos anos 1960 (1969: 3), voltou ao tema:

A fórmula era também um desafio. Nas discussões de São Paulo e nos intermináveis papos com Alinor Azevedo, nossa maior preocupação era a busca de um cinema legitimamente popular brasileiro. Por outro lado, abominávamos a alienação cosmopolita dos grandes estúdios paulistanos; por outro, lamentávamos o engodo das plateias populares através das chanchadas irresponsáveis. Fundador da Atlântida, Alinor seguira a lição de Favela dos meus amores, tanto em Moleque Tião (...), como em Tudo azul (...). Havia nesses filmes um filão a ser explorado: o dia a dia carioca em seus múltiplos aspectos: o samba, o morro, o carnaval, o subúrbio e a Zona Sul. 
Em tom de elogio, Tudo azul é visto por Viany como um "programa estético para um futuro cinema nacional-popular brasileiro". Dois anos depois de Tudo azul, o próprio Viany teceria mais um elo dessa tradição, com o seu filme Agulha no palheiro (Napolitano, 2011). O dilema desse tipo de cinema era como atrair o público galvanizado pela chanchada, sem recair no estereótipo do popular e no humor fácil do gênero. Para esses realizadores, a chanchada era a verdadeira esfinge cinematográfica brasileira a ser compreendida.

Paulo Emilio Salles Gomes aponta Tudo azul como parte de um processo de renovação da própria chanchada (Gomes, 1996:78). Máximo Barro aponta que os filmes Tudo azul (1951), de Moacyr Fenelon, e Carnaval no fogo indicam um ponto de transição entre o musical carnavalesco e os filmes paródicos de Carlos Manga realizados posteriormente, e que erroneamente são classificados como chanchadas (Barro, 2007: 251). A aludida "renovação da chanchada" passava pela tentativa de conciliar elementos típicos do gênero, como as apresentações musicais, os tipos populares e as situações humorísticas, com elementos do realismo e da crônica social, na busca de um cinema nacional-popular, mas que via de regra era formatado a partir de um olhar conservador, no qual as tensões de classe se resolviam pelo riso catártico. ${ }^{5}$

Paulo Emilio ainda vê a influência do PCB nesse projeto de cinema:

Esse clima intelectual e mais a prática do método neorrealista conduziram à realização de alguns filmes no Rio e em São Paulo que glosavam artisticamente a vida popular urbana. $\mathrm{O}$ antigo herói desocupado da chanchada foi suplantado pelo trabalhador (...) sem serem propriamente políticas ou didáticas essas fitas exprimiam uma consciência social corrente em nossa literatura pós-modernista, mas inédita em nosso cinema (Gomes, 1996: 99).

Talvez essa afirmação soe como exagero, ao comparar a canônica literatura da década de 1930 com o projeto de cinema que tentava a duras penas se afirmar nos anos 1950, esbarrando em entraves técnicos, comerciais e artísticos. O realismo nesses filmes era mais um objetivo, uma inspiração, do que propriamente um projeto estético maduro e consequente por parte dos realizadores, que em grande parte tinha a ver com como eles absorveram o impacto do neorrealismo italiano no final da Segunda Guerra Mundial.

Para Mariarosaria Fabris (2007: 82), o neorrealismo não deve ser visto como modelo do cinema brasileiro de intenções realistas, e sim como "elemento deflagrador" para a busca de uma cultura nacional (cinematográfica) autêntica. Segundo a autora: "A falta de uma definição melhor, esses filmes produzidos no 
Rio de Janeiro entre a segunda metade dos anos 1930 e a primeira metade dos anos 1950 foram denominados pré-neorrealistas, por retratarem frequentemente ambientes mais pobres e por serem rodados em parte em cenários naturais". Mariarosaria cita nominalmente alguns filmes dessa tradição: Favela dos meus amores, Moleque Tião, Também somos irmãos, Gente honesta, É proibido sonhar e... Tudo azul.

A relação entre chanchada e realismo, para alguns autores, não é assim tão antinômica. João Carlos Rodrigues (2007: 89) lembra que enquanto o musical norte-americano é fundamentalmente onírico, "a chanchada não dispensa a realidade, da qual é sátira ou paródia". ${ }^{6}$

Em Tudo azul, conforme Luis Alberto Rocha Melo, o ambiente onírico dos musicais e do carnaval é atravessado por imagens realistas do morro e do ambiente do rádio carioca. São inserções musicais extra-diegéticas, fantasiosas, pois o curso natural da narração, a partir do momento em que o filme é trabalhado sob o ponto de vista de um suicida agonizante, rompe com a diegese naturalista. Melo (2006: 97) divide o filme em duas metades distintas: a primeira "realista" (até o ato de suicídio de Ananias) e a segunda "onírica". Mas é curioso que o momento documental do filme, as imagens de favela feitas in loco, apareça no momento "onírico".

\section{A música como encenação dos espaços sociais}

Algumas sequências musicais são particularmente importantes como expressões de síntese da alquimia entre chanchada, fantasia musical e realismo proposta por Tudo azul.

Na encenação fílmica de Lata d'água, interpretada por Marlene no auge do seu sucesso, temos o grande momento de inserção do real na fantasia carnavalesca do moribundo compositor. As imagens saltam do apartamento (de ambiência modernista e de alta classe média) para a favela, com a liberdade antinaturalista dos musicais, perturbada porém pelo tom documental das imagens feitas in loco (Melo, 2006: 105).

A sequência se inicia com o "compositor consagrado" Ananias, instalado em um apartamento de ambiência modernista de classe média alta, aliás, um flagrante contraste com a casa suburbana do "pequeno funcionário", que sabemos ser a sua realidade efetiva.

Em uma situação inusitada, Ananias é disputado por duas mulheres, a esposa (que na fantasia já não é mais a megera, mas uma espécie de "Amélia" burguesa que tudo aceita) e a colega objeto do seu desejo. Mas Ananias, tal qual um gênio romântico irrequieto, não quer sair com nenhuma das duas. Quer sossego 
para dar vazão a uma obra que se lhe apresenta como inspiração inconclusa, como perturbação da alma. A esposa e a amante compreendem, e a primeira se retira de cena para deixar o gênio trabalhar em companhia da musa Marlene-Maria Clara. Na sequência ouvimos as primeiras notas de Lata d água ao piano, ainda em forma de esboço. Ao ouvir as notas, Marlene-Maria Clara é possuída pela música e, saltando do sofá onde se instalara, inicia uma coreografia com passos estilizados de samba. A luz escurece, o apartamento é tomado pela penumbra e, ao invés dos acordes iniciais e suaves do piano, explode um arranjo de batuques e orquestra (aliás, a cargo do maestro "Vero", pseudônimo de ninguém menos que Radamés Gnatalli). "Lata d'água na cabeça, lá vai Maria, lá vai Mariiiia... Sobe o morro e não se cansa, pela mão leva a criança, lá vai Maria..."

Lata d'Água apresenta "marias" diferentes da Maria Candelária, a marchinha que a precede no filme, ironizando a figura de uma funcionária pública apadrinhada, cujo expediente de trabalho se resume à sequência "à uma vai no dentista, às duas vai ao café, às três vai à modista, às quatro assina o ponto e dá no pé... que grande vigarista que ela é". A Maria de Lata d'Água é a mulher popular digna que sobe e desce o morro para cuidar da sua casa e da sua família. Assim, a favela irrompe no filme de Fenelon da maneira mais improvável: como tomadas em locação, em cenário realista do morro e com suas "marias" indo e vindo. Documentário imprevisto da miséria social, apresentado no filme como signo de inspiração e autenticidade para o compositor de classe média (imagem 2).

Imagem 2: A favela surge como realidade dentro do sonho.

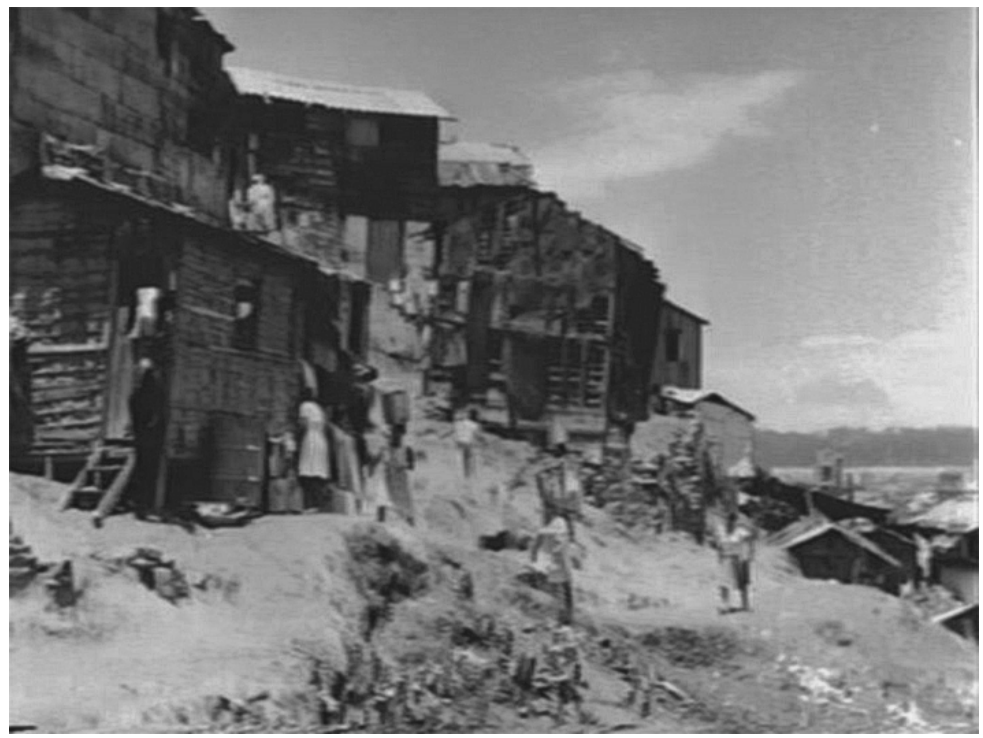


Imagem 3: as "marias" sem rosto e suas latas d'água na cabeça

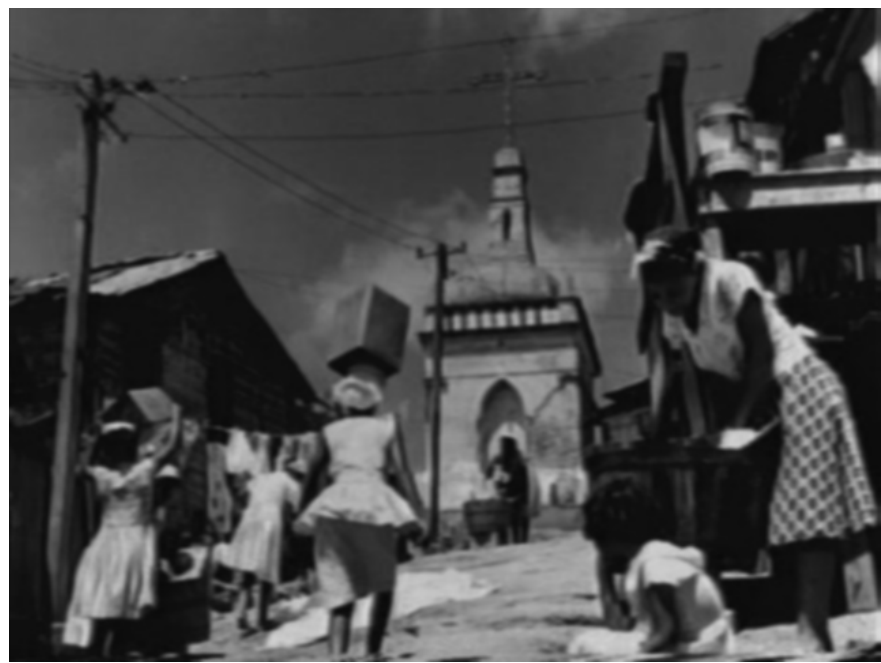

Imagem 4: O morro visto de baixo, em contra-plongée.

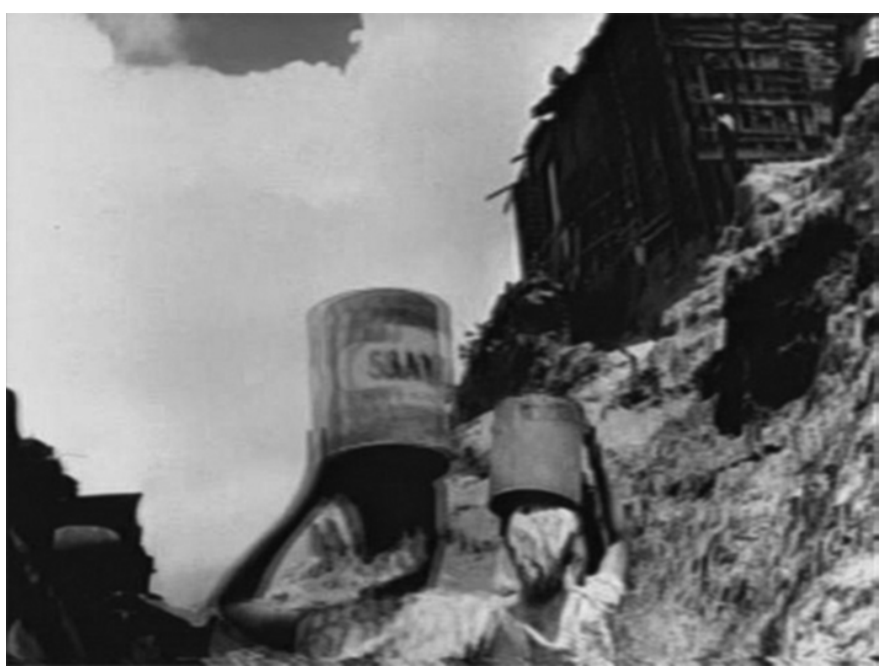

Ananias e Marlene criam inspirados por esse ambiente real, materializando a obra do primeiro na explosiva performance da segunda, cujo rosto em close é mesclado com as imagens da favela real, enquanto ouvimos sua voz interpretar a canção. O curioso é que entre o apartamento e a favela não há linha de 
tensão, pois a música "autêntica" projeta-se da ambiência cênica burguesa para o morro real. Não há bloqueio criativo ou impossibilidade de diálogo, como em Rio, Zona Norte, posto que a favela, antes de ser uma realidade perturbadora, é sobretudo mote inspirador visto à distância. O que observamos, na verdade, é a favela como paisagem sócio-musical e o favelado como parte desta. Nas sequências documentais, não há rostos individualizados ou interiores precários dos barra$\cos$ (imagem 3). A favela ainda é olhada de longe, aparece como paisagem social e humana vista pelos "de baixo", não socialmente, mas geograficamente, ou seja, vista do asfalto, "que acaba onde o morro principia". O ângulo inferior predominante no enquadramento das tomadas parece confirmar esse olhar (imagem 4).

Portanto, o outro, o favelado, ainda não é sujeito ou protagonista. Mas, inegavelmente, é um dado de realidade, perpassada pela fantasia musical carnavalesca, irrompendo fora do "palco italiano" das chanchadas (Machado, 1987: 192). A sequência expressa dois "desejos de fotogenia", ainda convivendo de forma ambígua: Marlene, expressão de um star system precário, ${ }^{7}$ cujo rosto em close pontua as imagens das "marias" sem rosto ${ }^{8}$ por outro lado, a favela, observada de longe, sugere que as "marias" homenageadas pela sua força e dignidade também são personagens que podem potencializar certa má consciência se observadas de muito perto. Em Tudo azul essa má consciência convive em com uma consciência amena da pobreza, que a vê como "típica" e como dado de "autenticidade cultural", parte integrante da paisagem dos morros cariocas. Só mais tarde essa consciência seria equacionada pelo cinema brasileiro, seja pelos casos limites do cinema musical popular, como em Rio Zona Norte, seja pelo olhar autoral, crítico e explicitamente politizado do Cinema Novo. ${ }^{9}$

Em contraponto, em outra sequência musical de Tudo azul, por conta de Grão de areia apresentada por Dalva de Oliveira junto com os membros da escola de samba. Império Serrano, a opção é outra. Na encenação do desfile, a fotogenia popular pode aparecer, ainda que componente de um sujeito coletivo já assimilado pela cultura carioca e brasileira, a Escola de Samba. Autorizadas pelo carnaval como inversão social e transgressão permitida, as classes populares mostram seu rosto digno e suas fantasias de requinte, homens de paletó, mulheres bem vestidas, e porta-bandeiras cheias de plumas e paetês (imagem 5).

O rádio e o teatro de revista complementam os espaços da fantasia musical do Ananias agonizante.

A encenação da canção Mundo de zinco com Jorge Goulart pode ser vista como um "documentário sobre o rádio" (Melo, 2006:103). Espaço de contradições, negociações e conflitos, o rádio experimentava nos anos 1950 uma grande expansão em direção a uma audiência popular, o que causava desconforto em alguns radialistas que idealizavam o rádio dos anos 1930 como uma comunidade 
mais sofisticada de ouvintes. Mesmo artistas e intelectuais de esquerda viam o mundo do rádio de maneira contraditória, um mundo pleno de possibilidades de expressão e comunicação com as massas, mas degradado pelos interesses comerciais e pela deturpação do que seria a boa e "autêntica" música popular brasileira, expropriada das classes populares e transformada em música puramente comercial.

Imagem 5: A fotogenia possível do popular: a Escola de Samba.

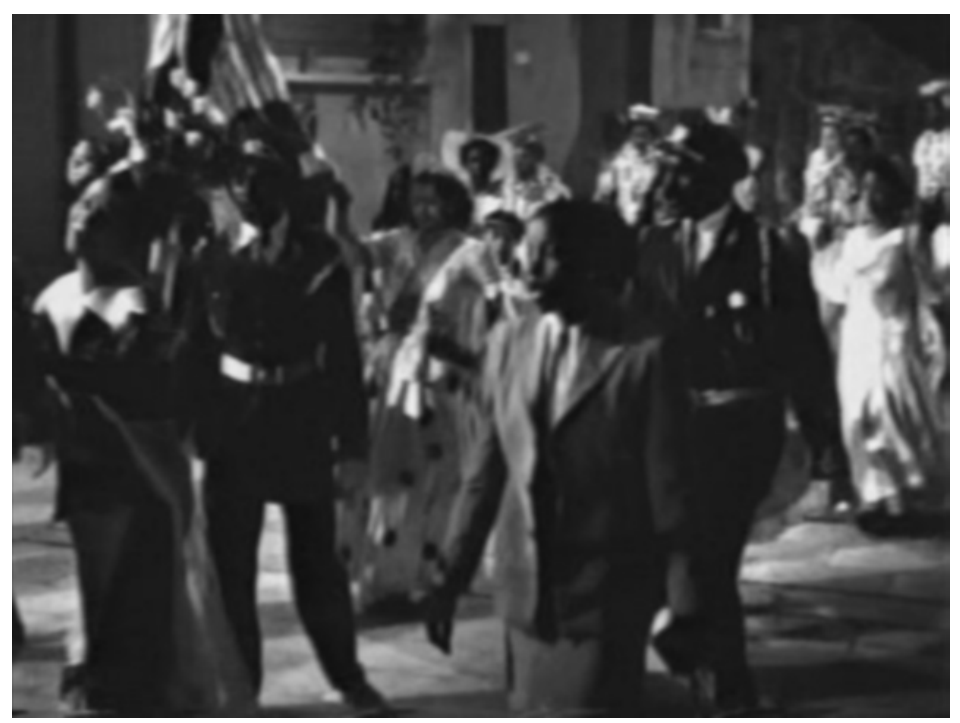

A marchinha Sassaricando nos lembra que o filme é tributário da chanchada. Virgínia Lane, a vedete símbolo daquele momento, apresenta a música acompanhada de uma encenação em forma de tableaux que funcionam como comentários pitorescos do cotidiano e das idiossincrasias da cidade do Rio de Janeiro (imagem 6).

Sassaricando, na verdade, serve como contraponto musical de uma das melhores sequências de Tudo azul, na qual o espaço de trabalho é subvertido pela música imaginada de Ananias, não para acabar com o capitalismo, mas para torná-lo humano e criativo. Aliás, ambas as posições caberiam em uma mensagem de "fundo socialista". Em resumo, na sua fantasia, Ananias imagina os donos da empresa Sevive dando-lhe carta branca para que ele, na "qualidade de poeta e compositor", utilize sua criatividade na busca da felicidade dos clientes e, posto que mais felizes estes viveriam mais tempo, de maiores lucros para a seguradora. 
Imagem 6:

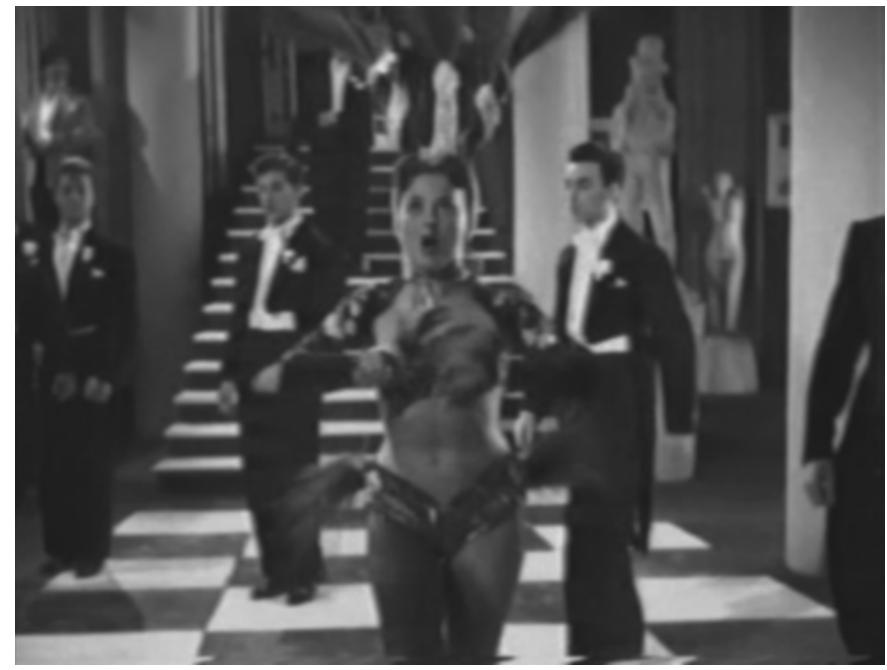

Em uma espécie de autogestão do próprio ritmo e conteúdo de trabalho, ainda na chave individualista e não como utopia coletiva, a sequência sugere que Ananias ganhara um poder de encantamento sobre os capitalistas, como um publicitário pós-moderno avant-la-lettre. Ele e sua música trazem criatividade à rotina burocratizada da empresa de seguros, fazendo sorrir os chefes carrancudos (imagem7).

Imagem 7: Os capitalistas se rendem ao compositor popular e também sassaricam.

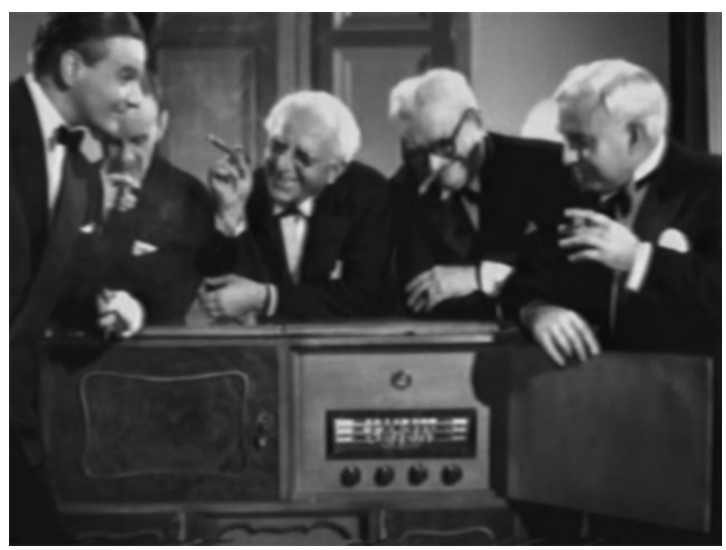


No mundo fantasioso de Tudo azul, valores humanistas, crítica social e utopia do trabalho desalienado convivem de maneira carnavalesca. A lógica do carnaval, ou seja, a inversão das hierarquias sociais e a fusão de espaços e tempos diferenciados, funde-se à crítica da alienação e da exclusão social, marca dos filmes realistas. Mas esse movimento não se radicaliza no filme de Fenelon, pois o apelo da chanchada carnavalesca ainda é forte, embora, como já dissemos, tensionado por outros elementos temáticos e narrativos.

A fantasia musical do agonizante Ananias, portanto, percorre vários espaços socioculturais, como se a consagração de sua música só fosse absoluta se circulasse por todas as audiências. $\mathrm{O}$ rádio, o teatro de revista, a rua do desfile carnavalesco, a boemia mundana, o ambiente de trabalho e a favela. $\mathrm{O}$ que nos importa sublinhar é que esse projeto de representar a música popular e seus personagens como um microcosmo das tensões sociais marcou o cinema dos anos 1950, tal como pensado pelos realizadores ligados ao nacionalismo de esquerda.

O final conformista e reconciliador com a realidade opressiva em Tudo $a z u l$ repõe a leveza da comédia carnavalesca, mas não deixa de expressar certas "reivindicações morais" do público e dos realizadores, sem as quais esse cinema nacional-popular com tons de esquerda não poderia acontecer como projeto. Portanto, o realismo no melodrama e na comédia musical não é propriamente fruto da reflexão sobre o mundo, e sim das impressões vagas que veiculam uma reivindicação moral do público que é assumida pelos realizadores, sobretudo aqueles ligados à tradição de esquerda. A "reivindicação moral” é uma espécie de petição crítica dentro da ordem e aceitação social, denunciando o sentimento de injustiça social "em abstrato". Conforme Silvia Oroz (1993:13):

A reivindicação moral é uma necessidade oculta do público, que a indústria cinematográfica do período que este artigo ocupa soube satisfazer plenamente a partir de um realismo ligado às impressões e não à reflexão do mundo. São as emoções que o espectador tem sobre a realidade que dão a base na qual se articula o realismo desta produção. É um realismo onde está presente o sentimento, mas não o significado, daí que não fornece uma ideia da dinâmica do mundo.

Por conta dessas opções contraditórias e da sua singularidade, fruto dessa oscilação entre a carnavalização e o olhar sobre o real (como crônica cotidiana e documentário involuntário sobre a pobreza), o crítico Anatol Rosenfeld afirmou que Tudo azul, mesmo nas "sequências carnavalescas de sonho - é mais realista e verdadeiro do que a maioria dos filmes de diversas proveniências anunciados como 'realistas". ${ }^{10}$ 
Essa estranha leveza carnavalesca de Tudo azul revela um processo de adensamento histórico e estético de uma linhagem de filmes que, de maneira errática e sofrendo das precariedades técnicas e artísticas do cinema brasileiro, tentou construir um cinema nacional-popular de cunho progressista. Esse aspecto articula a obra de Fenelon aos dois clássicos de Nelson Pereira dos Santos - Rio, 40 graus e Rio, Zona Norte, obras na qual esse adensamento chega ao limite. O Ananias de Tudo azul ainda não é o Espírito Soares da Luz de Rio, Zona Norte, embora o anuncie, dialeticamente falando: ambos são compositores inéditos, sonham com o estrelato do mundo do rádio, mas Ananias é branco e está mais para a classe média baixa do que para o proletariado da favela. Assim, Tudo azul deve ser analisado em si mesmo, como obra singular, mas também dentro de um projeto que foi animado por realizadores ideologicamente comprometidos com o nacionalismo de esquerda entre os anos 1940 e 1950, cujo projeto seria abortado pela afirmação do Cinema Novo como paradigma de cinema brasileiro politizado, independente e crítico.

Em ambos os projetos, apesar de suas diferenças estéticas radicais, os impasses na busca da fotogenia popular, da temática nacional e do papel do cinema como detonador de uma consciência crítica são faces diferentes da mesma utopia do cinema brasileiro.

O resultado final do filme, mesmo tendendo ao conformismo e ao apanágio das saídas individualistas para as angústias de um sistema competitivo e baseado no clientelismo, não deixa de ser um sintoma de um projeto de cinema que não negava as tensões sociais, mas também não abria mão da comunicação fácil com o público. O elo dessa comunicação eram os gêneros já consagrados, como a chanchada e o musical carnavalesco. Assim, a "busca do povo brasileiro" pelos artistas de esquerda dos anos 1950 era bem diferente do que veríamos nas duas décadas seguintes. Ainda havia espaço para conciliar escapismo carnavalesco e crítica realista, demarcando uma espécie de consciência amena do subdesenvolvimento, ao menos no campo do cinema. Nos anos 1960, o Cinema Novo apontaria para outros tipos de intervenção estética e ideológica. Mas foi depois de 1964, quando o regime militar mergulhou o Brasil numa grande quarta-feira de cinzas que duraria 20 anos, que esse projeto perdeu completamente seu vigor e seu lugar na cultura de esquerda. 
1. Neste artigo procurei seguir a perspectiva analítica lançada por Alex Viany (1959) e pela dissertação de Luis Alberto Rocha Melo (2006), amplamente citada a seguir, para analisar o filme Tudo azul.

2. Moacyr Fenelon foi técnico de som trabalhou com Lulu de Barros. Como sonoplasta trabalhou em Acabaram-se os otários (Lulu de Barros, 1929) e Coisas nossas (Wallace Downey, 1932), incorporando o sistema Vitaphone (gravação do som em discos sincronizados ao filme). Foi técnico de som na Waldow Filmes, incorporando o Movietone (som impresso na película) no filme Estudantes (Wallace Downey, 1935). Estreou na direção em $O$ simpático feremias (1940). Fundou a Flama Filmes, em associação com Rubem Berardo.

3. Ver Lenharo, Alcir (1995). Nesse livro, Lenharo traça um painel histórico do ambiente do rádio e do comércio varejista de canções entre compositores e intérpretes.

4. Ver Ficha Técnica do filme ao final deste artigo, com a autoria das canções citadas.

5. Um dos filmes exemplares nesse sentido, ponto de tensão entre o "moderno, o popular e o autêntico" já no início da década de 1960, é Samba em Brasília (Watson Macedo), no qual o morro é lugar da felicidade e da autenticidade. Mas nesse caso, estamos em um caso limite, que não sobreviveria ao furacão criativo do cinema novo. Ver Kornis (2004).

6. Para João Carlos Rodrigues, a influência da chanchada brasileira vem mais do rádio e do teatro de revista carioca. $\mathrm{O}$ material extraído da realidade política, social, ou das mudanças no cotidiano urbano também remete à tradição das revistas desde o tempo do Império. Os números cantados eram superiores aos números dançados. Outro elemento das chanchadas é a su- bordinação ao rádio e seus sucessos musicais (Rodrigues, 2007: 89).

7. Sobre a precariedade técnica do star system do cinema brasileiro à época, ver Margarida Adamatti (2008).

8. O racismo sutil desta sequência foi apontado por Robert Stam (2008: 474).

9. Conforme Hilda Machado (1987: 150): “O pobre não é filmavel. É filmável a cara do pobre, o barraco do pobre, mas o pobre - essa relação, abstração, construção humana - não imprime no negativo. Filmamos todos metonímias."

10. Ver Rosenfeld (c.1951: 48): "Esta realização de Moacyr Fenelon é um dos mais curiosos filmes de carnaval já vistos - um filme de carnaval amargo, irônico e, contudo, não derrotista. Enfim, um filme de carnaval inteligente, o que não deixa de ser uma façanha extraordinária. É um filme que mesmo na sua parte central - nas sequências carnavalescas de sonho - é mais realista e verdadeiro do que a maioria dos filmes de diversas proveniências anunciados como 'realistas"'.

\section{Ficha técnica de Tudo azul (1951)}

Categorias: Longa-metragem / Sonoro / Ficção

Material original: $35 \mathrm{~mm}, \mathrm{BP}, 80 \mathrm{~min}$, $2.400 \mathrm{~m}, 24 \mathrm{q}$, DEB - Duvergé Emon Bonfanti, 1:1'37

Data e local de produção:

Ano: 1951

País: BR

Cidade: Rio de Janeiro

Estado: DF 
Certificados: Recensurado em 17.12.1959, $2.400 \mathrm{~m}, 35 \mathrm{~mm}, 20$ cópias, livre. Recensurado em $17.12 .1959,960 \mathrm{~m}, 16 \mathrm{~mm}, 10$ cópias.

Sinopse: Homem simples e dedicado marido sonha ver suas composições gravadas. Após uma crise conjugal, tenta o suicídio tomando barbitúricos. Entra em transe e, através de um sonho, vê suas músicas fazendo sucesso. Quando acorda, percebe que tudo não passou de uma ilusão, mas sua vida não será mais a mesma. (ALSN/ DFB-LM)

Gênero: Drama

Dados de produção:

Companhia(s) produtora(s): Flama Produtora Cinematográfica Ltda.

Produção: Berardo, Rubens

Direção de produção: Rio, Mario Del

Coordenação de produção: Valverde, Rafael Justo

Companhia(s) distribuidora(s): Cinedistri

- Produtora e Distribuidora de Filmes do Brasil

Argumento: Pongetti, Henrique; Azevedo, Alinôr

Direção: Fenelon, Moacyr

Coreografia: Silva, Lauro

Direção de fotografia: Pagés, Mario

Cinegrafista: Carneiro, Silvio

Técnico de som: Baschera, Ercole
Montagem: Valverde, Rafael Justo

Cenografia: Olivo, Pablo

Identidades/elenco: Marlene; Delfino, Luiz; Suarez, Laura; Carneiro, Milton; Nobre, Antônio; Rodrigues, Benito; Martins, João; Kaiuca, Elias; Macedo, Zizinha; Nogueira Sobrinho; Coutinho, Arnaldo

Canções apresentadas no filme (em ordem alfabética):

Apanhador de papel (Peterpan / Afonso Teixeira), com os Quatros Ases e Um Curinga

Deixa essa mulher chorar (Sílvio Caldas), com Linda Batista;

Estrela do mar (Marino Pinto e Paulo Soledade), com Dalva de Oliveira e a Escola de Samba Império Serrano;

Eva (Haroldo Lobo e Milton de Oliveira), com Marlene;

Isto é baião (HumbertoTeixeira), com Carmélia Alves;

Lata d'água (Luiz Antônio e Jota Júnior) com Marlene;

Maria Candelária (Armando Cavalcanti e Klécius Caldas), com Blecaute;

Mundo de zinco (Nássara e Wilson Batista), com Jorge Goulart e o Regional de Dante Santoro;

Sassaricando (Luiz Antônio, Zé Mário / Oldemar Magalhães), com Virgínia Lane. 
Referências bibliográficas

ADAMATTI, Margarida. A crítica cinematográfica e o star system nas revistas de fãs: $A$ Cena Muda e Cinelândia (1952-1955). Dissertação (Mestrado em Ciências da Comunicação), 2008.

BARRO, Máximo. Fosé Carlos Burle. Drama na chanchada. Col. Aplauso, São Paulo: Imprensa Oficial, 2007.

CHION, M. La musica em el cine. Barcelona: Paidos, 1997.

FABRIS, Mariarosaria. A questão realista no cinema brasileiro: aportes neorrealistas. Alceu, v.8, n.15, jul-dez 2007, 82-94.

GOMES, Paulo Emilio Sales. Cinema: trajetória no subdesenvolvimento. São Paulo: Paz e Terra, 1996.

KORNIS, Mônica. Samba em Brasília: uma utopia conservadora dos anos 1950. Cadernos de Antropologia e Imagem. 18/1, 2004, p. 135-144.

LENHARO, Alcir. Cantores do Rádio. A trajetória de Nora Ney e Forge Goulart e o meio artístico do seu tempo. Campinas: Editora da Unicamp, 1995.

MACHADO, Hilda. Rio 40 e Rio Zona Norte. O jovem Nelson Pereira dos Santos. Dissertação, ECA, 1987.

MELO E SOUZA, José Inácio. Congressos, patriotas, ilusões e outros ensaios. São Paulo: Linear B, 2005.

MELO, Luis Alberto Rocha. Argumento e roteiro: o escritor de cinema Alinor Azevedo. Dissertação (Mestrado em Comunicação), UFF, Niterói, 2006, p. 91

NAPOLITANO, Marcos. O fantasma de um clássico: recepção e reminiscências de Favela dos meus amores (Humberto Mauro,
1935). Significação (UTP), v. 32, 2009, 157-170.

As interferências do real no melodrama musical de esquerda: uma análise do filme Agulha no palheiro (Alex Viany, 1953). Comunicação apresentada no Simpósio Nacional de História, ANPUH, São Paulo, 2011.

OROZ, Silvia. Notas introductorias al realismo social em $\mathrm{El}$ cine de La industria cinematográfica latinoamericana - décadas de 30 a 50. Comunicação \& Política na América Latina, 18/19, São Paulo: CBELA, 1993.

RODRIGUES, João Carlos. Musical e chanchada. In: BENTES, Ivana (org.). Ecos do cinema. De Lumière ao digital. Rio de Janeiro: Editora da UFRJ, 2007.

ROSENFELD, Anatol. Crítica do filme Tudo azul, Iris: Revista Brasileira de Foto (c.1951). p. 48.

STAM, Robert. Multiculturalismo tropical: uma história comparativa da raça na cultura e no cinema brasileiros. Tradução de Fernando Vulgman. São Paulo: EDUSP, 2008.

VELLOSO, Mônica Pimenta. A dupla face de Jano: romantismo e populismo. In: GOMES, Ângela de Castro (org.). O Brasil de FK. $2^{\mathrm{a}}$ ed. Rio de Janeiro: Ed. FGV/ CPDOC, 2002, p.171-200.

VIANY, Alex. Introdução ao cinema brasileiro. Rio de Janeiro: INC, 1959.

. Depoimento. Acervo Cinemateca do MAM/RJ, mimeo, maio de 1969.

VILHENA, Rodolfo. Projeto e missão. O movimento folclorista brasileiro. Rio de Janeiro: Civilização Brasileira, 1997. 


\section{Resumo}

O filme Tudo azul (1951), dirigido por Moacyr Fenelon, foi um dos momentos do projeto de um cinema nacional-popular, apoiado por realizadores de esquerda, na tentativa de articular crítica social e diversão. Ao narrar a angústia do "pequeno funcionário" Ananias, compositor inédito e pai de vários filhos que trabalha em uma companhia de seguros mas sonha em ser compositor famoso, Tudo azul representa uma tentativa em conciliar elementos da chanchada carnavalesca e do melodrama com a perspectiva realista.

Palavras-chave: história e cinema: Brasil; cinema e música popular.

\section{Abstract}

The film Tudo azul (1951), directed by Moacyr Fenelon, was part of a national-popular cinema project, backed by leftist filmmakers, in an attempt to articulate social criticism in a light-hearted manner. In recounting the anguish of Ananias, a minor official, unknown composer and father of several children who works at an insurance company but dreams of becoming a famous songwriter, Tudo azul represents an attempt to combine elements of carnivalesque slapstick and melodrama from a realistic perspective.

Key words: history and cinema: Brazil; cinema and popular music.

\section{Résumé}

Le film Tudo azul (1951), réalisé par Moacyr Fénelon, a eté un des exemples d'un projet de cinéma national-populaire, soutenu par des cinéastes de gauche dans l'effort d'articuler critique sociale et divertissement. En racontant l'angoisse d'Ananias, compositeur inconnu et père de plusieurs enfants qui travaille dans une compagnie d'assurance, mais rêve de devenir un auteur-compositeur célèbre, Tudo azul représente une tentative de combiner des éléments de carnaval burlesque (chanchada) et le mélodrame, traversé par une perspective réaliste.

Mots-clés: histoire et cinéma: Brésil; cinéma et musique populaire. 